\title{
A Delphi study to identify prehospital and emergency department trauma care modifiers for older adults
}

\author{
Krishan Yadav, MD, MSc \\ Valérie Boucher, MSc \\ Natalie Le Sage, MD, PhD \\ Christian Malo, MD, MSc \\ Éric Mercier, MD, MSc \\ Philippe Voyer, RN, PhD \\ Julien Clément, MD \\ Marcel Émond, MD, MSc
}

Accepted July 6, 2020

\author{
Correspondence to: \\ K. Yadav \\ Department of Emergency Medicine \\ University of Ottawa \\ Room F647, 1053 Carling Ave \\ Ottawa ON K1Y 4E9 \\ kyadav@toh.ca
}

DOI: $10.1503 /$ cjs.021519

\begin{abstract}
Background: Older patients (age $\geq 65 \mathrm{yr}$ ) with trauma have increased morbidity and mortality compared to younger patients; this is partly explained by undertriage of older patients with trauma, resulting in lack of transfer to a trauma centre or failure to activate the trauma team. The objective of this study was to identify modifiers to the prehospital and emergency department phases of major trauma care for older adults based on expert consensus.
\end{abstract}

Methods: We conducted a modified Delphi study between May and September 2019 to identify major trauma care modifiers for older adults based on national expert consensus. The panel consisted of 24 trauma care professionals from across Canada from the prehospital and emergency department phases of care. The survey consisted of 16 trauma care modifiers. Three online survey rounds were distributed. Consensus was defined a priori as a disagreement index score less than 1 .

Results: There was a $100 \%$ response rate for all survey rounds. Three new trauma care modifiers were suggested by panellists. The panel achieved consensus agreement for 17 of the 19 trauma care modifiers. The prehospital modifier with the strongest agreement to transfer to a trauma centre was a respiratory rate less than 10 or greater than $20 \mathrm{breaths} / \mathrm{min}$ or need for ventilatory support. The emergency department modifier with the strongest level of agreement was obtaining 12-lead electrocardiography following the primary and secondary survey.

Conclusion: Using a modified Delphi process, an expert panel agreed on 17 trauma care modifiers for older adults in the prehospital and emergency department settings. These modifiers may improve the delivery of trauma care for older adults and should be considered when developing local and national trauma guidelines.

Contexte : Les polytraumatisés âgés ( $\geq 65$ ans) sont exposés à un risque plus grand de morbidité et de mortalité comparativement aux jeunes polytraumatisés; cela s'explique en partie par un triage inadéquat des patients âgés victimes de traumatismes, qui fait en sorte qu'on ne les oriente pas vers un centre de traumatologie ou qu'on ne fait pas intervenir l'équipe de traumatologie. L'objectif de la présente étude était d'identifier les éléments de soins à modifier au stade préhospitalier et en médecine d'urgence lors de la prise en charge des cas de traumatismes graves chez les adultes âgés, sur la base d'un consensus d'experts.

Méthodes : Nous avons procédé à une analyse Delphi modifiée entre mai et septembre 2019 pour recenser les éléments de soins à modifier chez les polytraumatisés âgés à partir d'un consensus national d'experts. Le panel d'experts se composait de 24 professionnels en traumatologie du Canada entier chargés des soins au stade préhospitalier et en médecine d'urgence. Le questionnaire portait sur 16 éléments à modifier en traumatologie. Trois questionnaires successifs ont été distribués en ligne. Le consensus était défini a priori par un indice de désaccord inférieur à 1 .

Résultats : Le taux de réponse a été de $100 \%$ pour les 3 questionnaires. Les membres du comité ont suggéré 3 nouveaux éléments à modifier. Le comité est arrivé à un consensus pour 17 des éléments à modifier sur 19. L'élément préhospitalier ayant fait l'objet du plus solide consensus concernant le transfert vers un centre de traumatologie était une fréquence respiratoire inférieure à 10 ou supérieure à 20 respirations/minute ou la nécessité d'une assistance respiratoire. L'élément à modifier parmi les soins prodigués à l'urgence ayant fait l'objet du plus solide consensus après les 2 premiers questionnaires était l'obtention d'un électrocardiogramme à 12 dérivations. 
Conclusion : À l'aide d'une analyse Delphi modifiée, un comité d'expert s'est entendu sur 17 éléments de soins à modifier chez les polytraumatisés âgés au stade préhospitalier et en médecine d'urgence. Ces éléments pourraient améliorer les soins aux adultes âgés et méritent d'être pris en compte lors de la création de lignes directrices locales et nationales en traumatologie.

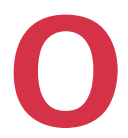

ver the past 20 years, the life expectancy and healthadjusted life expectancy (i.e., taking into account morbidity and mortality) among Canadians have continued to rise. ${ }^{1}$ With people living longer, older adults (age $\geq 65 \mathrm{yr}$ ) now constitute a substantial proportion of the trauma population. Older adults are becoming increasingly involved in major trauma, which is often defined as an Injury Severity Score greater than $15 .^{2}$ One-third of all injuryrelated deaths among males and two-thirds of such deaths among females occur in those aged 65 years or older. ${ }^{3}$ Patients aged 75 years or older have become the secondlargest age group in the British major trauma population. ${ }^{4}$ In Australia, the number of patients aged 65 or older with major trauma doubled from 2007 to 2016.5

Delivery of care for major trauma in this growing age group remains complex. ${ }^{6-8}$ Older patients with trauma are at risk for increased morbidity and prolonged hospital length of stay. ${ }^{9,10}$ Older patients experience major trauma from low-velocity mechanisms, such as falls from $1 \mathrm{~m}$ or less. ${ }^{5}$ Several studies have shown that older patients with trauma have increased mortality compared to younger patients. ${ }^{9-12}$ This may be partly explained by undertriage of older patients, which results in lack of transfer to a trauma centre or failure to activate the trauma team. ${ }^{13-20}$ Triaging older people with trauma appropriately using objective findings is challenging owing to the physiologic differences between older and younger patients. For example, Kehoe and colleagues ${ }^{21}$ found that older patients with a traumatic brain injury presented with a higher Glasgow Coma Scale score than younger patients. Heffernan and colleagues ${ }^{22}$ reported significantly increased mortality in patients aged 65 or older with trauma who presented with a systolic blood pressure less than $110 \mathrm{~mm} \mathrm{Hg}$ (v. > $95 \mathrm{~mm} \mathrm{Hg}$ in younger patients) and heart rate greater than 90 beats/min (v. > 130 beats $/ \mathrm{min}$ in younger patients). Older patients with trauma may have occult hypoperfusion, which renders the presence of "normal" initial vital signs unreliable.

Given these challenges in caring for older adults, there have been calls to adapt major trauma care. Examples include modification of conventional Glasgow Coma Scale cut-off values ${ }^{23}$ and initial vital signs ${ }^{22,24}$ for older patients. Other authors have recommended using markers such as serum lactate level and base deficit ${ }^{25-29}$ as alternative predictors of mortality. Ultimately, it is clear that modifications to conventional geriatric trauma care are required to improve patient outcomes. The objective of this study was to identify modifiers to the prehospital and emergency department phases of major trauma care for older adults based on expert consensus.

\section{MethodS}

\section{Study design}

We conducted a modified Delphi study to select major trauma care modifiers for older adults based on national expert consensus. This study was completed in accordance with accepted Delphi methodology. ${ }^{30-32}$ The local research ethics board (Comité d'éthique du CHU de Québec-Université Laval) approved this study (\#MP-202017-3180).

\section{Generation of trauma care indicators and modifiers}

We defined a trauma care indicator as a metric, outcome or intervention that is currently used in the delivery of trauma care. An example of a trauma care indicator is a systolic blood pressure cut-off value of less than $90 \mathrm{mmHg}$ to trigger field triage to a trauma centre. ${ }^{33}$ We defined a trauma care modifier as an adaptation of a currently used indicator to provide trauma care to older adults. An example of a trauma care modifier is substituting a systolic blood pressure cut-off value of less than $110 \mathrm{~mm} \mathrm{Hg}$ rather than less than $90 \mathrm{~mm} \mathrm{Hg}$ to trigger field triage for patients with trauma aged 65 years or older. ${ }^{34}$

After performing a literature search and reviewing guidelines (guidelines for field triage of injured patients: recommendations of the National Expert Panel on Field Triage, 2011, ${ }^{33}$ Advanced Trauma Life Support, ${ }^{6}$ evaluation and management of geriatric trauma: an Eastern Association for the Surgery of Trauma practice management guideline $\mathrm{e}^{35}$ ), we created a list of 16 trauma care indicators and modifiers for older adults based on consensus among local experts in trauma and emergency medicine.

\section{Survey development}

We developed a survey consisting of the 16 trauma care indicators and modifiers for older adults in both English and French (Appendix 1, available at canjsurg.ca/021519-a1). Selected emergency and trauma physicians not involved as expert panellists were asked to assess the survey for content and face validity. Participants were asked to rank each item on a Likert scale ranging from 1 (strongly disagree) to 9 (strongly agree). A free-text section of the survey allowed for suggestions of new modifiers and feedback. We collected and managed the survey data using REDCap electronic data capture tools hosted at the CHU de Québec-Université Laval. 


\section{Recruitment and panel selection}

We identified the following health care roles as important to the prehospital and emergency department phases of trauma care: emergency medical services director, paramedics, trauma surgeons, emergency physicians, emergency nurses and trauma administrators. We required a group of about 20-30 health care professionals in these various roles with expertise in trauma from across Canada. A similar number of experts has been previously used for Delphi studies in trauma. ${ }^{36-38}$ We sent a prenotification email to trauma health care professionals, inviting them to participate in the panel.

\section{Delphi procedure}

A maximum of 3 survey rounds was planned a priori. The first survey was distributed on May 21, 2019, and the final survey was distributed on Sept. 10, 2019. Each electronic survey was followed up by up to 3 email reminders spaced at 1-week intervals. For the second and third survey rounds, participants were able to view their own scores from the previous round, in addition to the blinded group scores and median score. Participants were asked to rescore items that did not achieve consensus in the prior round. After completion of the final round, anonymized results were distributed to the participants.

\section{Statistical analysis}

We used the RAND/UCLA appropriateness method ${ }^{30}$ to classify items according to the following predetermined thresholds: appropriate (median score 7-9, without disagreement), uncertain (median score 4-6, or any median with disagreement) or inappropriate (median score 1-3, without disagreement). We calculated the interpercentile range adjusted for symmetry to quantify the level of agreement. ${ }^{30}$ We selected a stricter 90 th percentile-10th percentile interpercentile range a priori for better discriminating power. We used the interpercentile range adjusted for symmetry to calculate the disagreement index (DI), where a DI score less than 1 indicates agreement and a DI score of 1 or greater indicates disagreement (Appendix 2, available at canjsurg.ca/021519-a2).

\section{RESULtS}

Of the 30 trauma health care professionals who received the prenotification email, 24 agreed to participate, and 6 declined or did not respond. The 24 panellists included an equal number of trauma surgeons, emergency physicians, emergency nurses and prehospital personnel (medical directors and paramedics) (Table 1). The majority (15 [62\%]) were male. Most participants had 5-20 years of practice experience and practised in an academic teaching
Table 1. Baseline characteristics of Delphi survey participants

\begin{tabular}{|lc|}
\hline Characteristic & $\begin{array}{c}\text { No. }(\%) \text { of } \\
\text { participants } \\
n=24\end{array}$ \\
\hline Gender & $15(62)$ \\
\hline Male & $9(38)$ \\
\hline Female & \\
\hline Health care provider role & $5(21)$ \\
\hline Trauma surgeon & $5(21)$ \\
\hline Emergency physician & $5(21)$ \\
\hline Emergency nurse & $4(17)$ \\
\hline Trauma administrator & $3(12)$ \\
\hline Paramedic & $2(8)$ \\
\hline Medical director/emergency physician & \\
\hline Main practice setting & $17(71)$ \\
\hline Academic teaching hospital & $3(12)$ \\
\hline Community teaching hospital & $1(4)$ \\
\hline Community nonteaching hospital & $3(12)$ \\
\hline Prehospital & \\
\hline Province & $9(38)$ \\
\hline Quebec & $9(38)$ \\
\hline Ontario & $3(12)$ \\
\hline British Columbia & $1(4)$ \\
\hline Alberta & $1(4)$ \\
\hline Manitoba & $1(4)$ \\
\hline Nova Scotia & $5(21)$ \\
\hline Years of practice & $8(33)$ \\
\hline$<5$ & $7(29)$ \\
\hline $5-10$ & $4(17)$ \\
\hline $11-20$ & \\
\hline$>20$ & \\
\hline & \\
\hline
\end{tabular}

hospital. The 3 paramedics on the expert panel were asked questions pertaining only to the prehospital trauma care modifiers. The remaining 21 panellists answered questions pertaining to both the prehospital and the emergency department phases of trauma care. The response rate was $100 \%$ for all 3 survey rounds.

Three new trauma care modifiers were suggested by panellists after the first 2 rounds (Figure 1). Thus, 19 trauma care modifiers (11 prehospital and 8 emergency department) were rated. Of the 19 modifiers, 17 (10 prehospital and 7 emergency department) achieved consensus agreement (Figure 1).

Table 2 shows the 10 prehospital trauma care modifiers that the expert panel agreed should be indications for transport to a trauma centre for adults aged 65 or older with major trauma. The 3 modifiers with the strongest agreement were respiratory rate less than 10 or more than 20 breaths/min, or need for ventilatory support (DI 0.24); treatment with an anticoagulant (warfarin or direct oral anticoagulant) and evidence of a head injury (DI 0.29); and falls from more than $2 \mathrm{~m}$ (DI 0.29).

Table 3 lists the 7 trauma care modifiers for older adults with major trauma in the emergency department phase of trauma care that reached agreement among the expert panel. The 3 modifiers with the strongest level of agreement were obtaining 12-lead electrocardiography after the primary and 


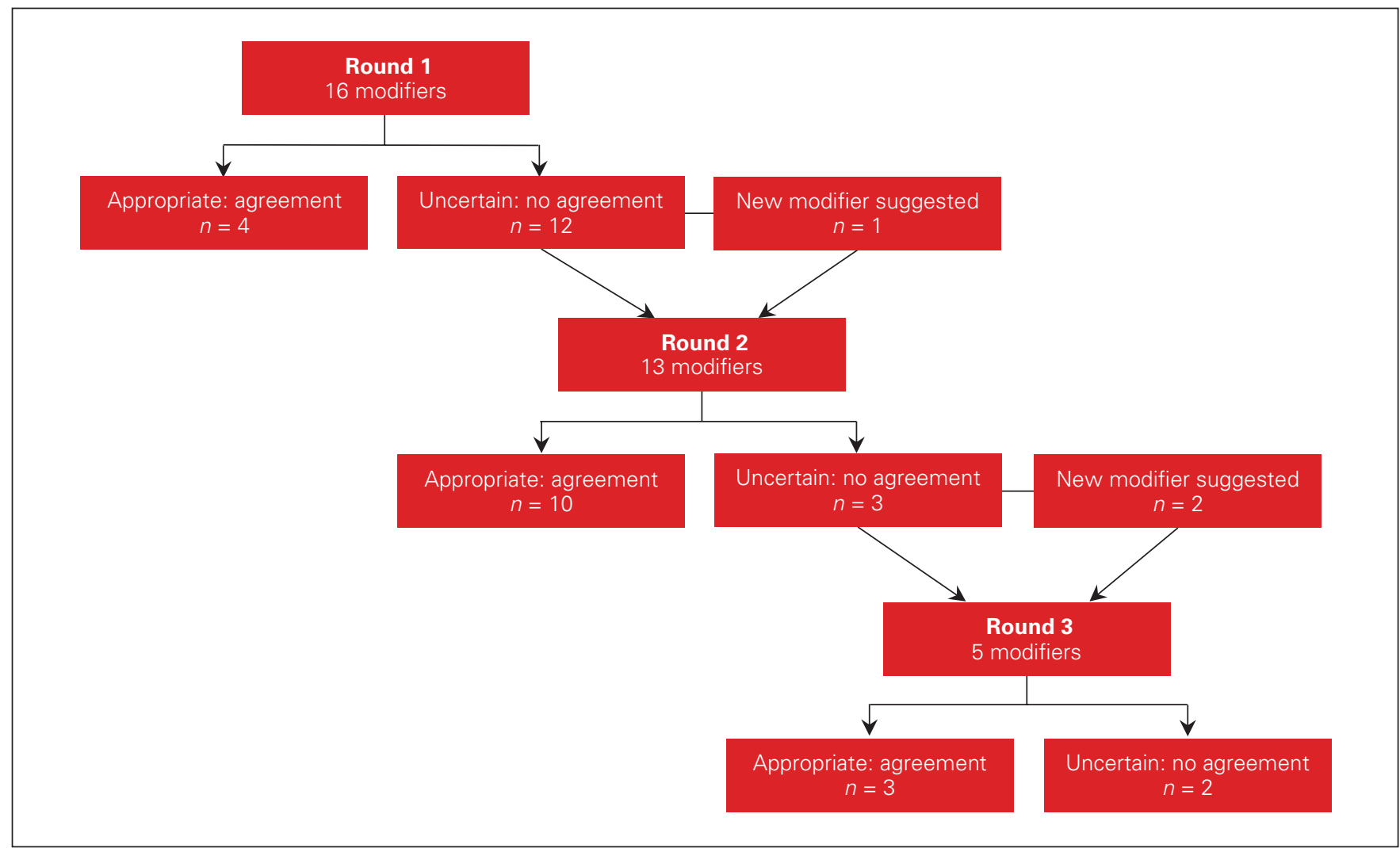

Fig. 1. Delphi process.

\begin{tabular}{|c|c|c|c|c|}
\hline \multirow[b]{2}{*}{ Trauma care modifier } & \multirow{2}{*}{$\begin{array}{l}\text { Median } \\
\text { importance }\end{array}$} & \multicolumn{3}{|c|}{ Round; disagreement index* } \\
\hline & & 1 & 2 & 3 \\
\hline Older patients with major trauma & 8.0 & 0.66 & - & - \\
\hline $\begin{array}{l}\text { Older patients with major trauma who are pedestrians/bicyclists } \\
\text { struck by a vehicle at ANY speed or involved in a motorcycle crash at } \\
\text { ANY speed }\end{array}$ & 8.0 & 0.66 & - & - \\
\hline $\begin{array}{l}\text { Older patients with major trauma taking anticoagulants (e.g., warfarin } \\
\text { or direct oral anticoagulant) with evidence of a head injury }\end{array}$ & 8.5 & 0.29 & - & - \\
\hline $\begin{array}{l}\text { Older patients with major trauma with a Glasgow Coma Scale score } \\
<15 \text { or not at their baseline mental status (i.e., patients with } \\
\text { dementia not at their baseline) }\end{array}$ & 8.0 & 1.62 & 0.66 & - \\
\hline $\begin{array}{l}\text { Older patients with major trauma with a systolic blood pressure } \\
<110 \mathrm{~mm} \mathrm{Hg}\end{array}$ & 8.0 & 1.56 & 0.97 & - \\
\hline $\begin{array}{l}\text { Older patients with major trauma with a respiratory rate of }<10 \text { or } \\
>20 \text { breaths/min or needing ventilatory support }\end{array}$ & 8.0 & 2.26 & 0.24 & - \\
\hline Older patients with major trauma with $\geq 1$ long-bone fracture & 8.0 & 2.26 & 0.43 & - \\
\hline Older patients with major trauma with $\geq 2$ suspected rib fractures & 8.0 & NA & 0.75 & - \\
\hline Older patients with major trauma with falls $>2 \mathrm{~m}$ & 8.0 & NA & NA & 0.29 \\
\hline $\begin{array}{l}\text { Older patients with major trauma with ground-level falls who are } \\
\text { taking anticoagulants (e.g., warfarin or direct oral anticoagulant) }\end{array}$ & 8.0 & NA & NA & 0.49 \\
\hline $\begin{array}{l}\text { NA }=\text { not applicable. } \\
{ }^{*}<1=\text { agreement }, \geq 1=\text { disagreement. }\end{array}$ & & & & \\
\hline
\end{tabular}

secondary survey (DI 0.01); obtaining a serum lactate or base deficit value on arrival at the emergency department (DI 0.49); and addressing the level of pain as soon as possible, with administration of opioids (weight-based dosing), when required, to prevent undertreatment of pain (DI 0.49).
Two trauma care modifiers failed to reach consensus agreement: transporting older patients with major trauma with ground-level falls to a trauma centre; and activating the trauma team for patients aged 65 or older with major trauma (Table 4). 
Table 3. Panel agreement ( $n=21$ ) on appropriateness of trauma care modifiers on arrival at emergency department for patients aged 65 years or more with major trauma

\begin{tabular}{|c|c|c|c|c|}
\hline \multirow[b]{2}{*}{ Trauma care modifier } & \multirow{2}{*}{$\begin{array}{l}\text { Median } \\
\text { importance }\end{array}$} & \multicolumn{3}{|c|}{ Round; disagreement index* } \\
\hline & & 1 & 2 & 3 \\
\hline $\begin{array}{l}\text { Signs of head injury (e.g., altered mental status, headache, vomiting, } \\
\text { scalp laceration or hematoma) in older patients with major trauma taking } \\
\text { anticoagulants (e.g., warfarin or direct oral anticoagulant) should be a } \\
\text { criterion for trauma team activation }\end{array}$ & 9.0 & 0.75 & - & - \\
\hline $\begin{array}{l}\text { A Glasgow Coma Scale score }<15 \text { or evidence that the patient is not at } \\
\text { his or her baseline mental status in older patients with major trauma } \\
\text { should be a criterion for trauma team activation }\end{array}$ & 7.0 & 2.26 & 0.65 & - \\
\hline $\begin{array}{l}\text { A heart rate }>90 \text { beats/min at any time should be a criterion for trauma } \\
\text { team activation in older patients with major trauma }\end{array}$ & 7.0 & 1.61 & 0.52 & - \\
\hline $\begin{array}{l}\text { Older patients with major trauma should have a serum lactate and/or } \\
\text { base deficit value obtained on hospital arrival }\end{array}$ & 8.0 & 1.09 & 0.49 & - \\
\hline $\begin{array}{l}\text { Following the primary and secondary survey, 12-lead electrocardiography } \\
\text { should be obtained in all older patients with major trauma }\end{array}$ & 9.0 & 1.56 & 0.01 & - \\
\hline $\begin{array}{l}\text { Level of pain should be addressed as soon as possible in older patients } \\
\text { with major trauma; when required, opioid analgesia should be } \\
\text { administered according to weight-based dosing to prevent } \\
\text { undertreatment of pain }\end{array}$ & 9.0 & 1.09 & 0.49 & - \\
\hline $\begin{array}{l}\text { A systolic blood pressure }<110 \mathrm{~mm} \mathrm{Hg} \text { at any time in older patients with } \\
\text { major trauma should be a criterion for trauma team activation }\end{array}$ & 7.0 & 2.26 & 2.55 & 0.65 \\
\hline
\end{tabular}

Table 4. Trauma care modifiers on which panellists did not reach agreement

\begin{tabular}{|c|c|c|c|c|}
\hline \multirow[b]{2}{*}{ Trauma care modifier } & \multirow{2}{*}{$\begin{array}{l}\text { Median } \\
\text { importance }\end{array}$} & \multicolumn{3}{|c|}{ Round; disagreement index* } \\
\hline & & 1 & 2 & 3 \\
\hline $\begin{array}{l}\text { Older patients with major trauma with ground-level falls should be } \\
\text { transported to a trauma centre }\end{array}$ & 6.0 & 2.26 & 2.33 & 2.31 \\
\hline $\begin{array}{l}\text { Age } \geq 65 \text { yr in patients with major trauma should be a criterion for trauma } \\
\text { team activation }\end{array}$ & 7.0 & 2.26 & 1.56 & 1.04 \\
\hline
\end{tabular}

\section{Discussion}

In this Delphi study to identify potential modifiers of trauma care for adults aged 65 years or older, we achieved a $100 \%$ response rate for all 3 survey rounds. The expert panel identified 17 trauma care modifiers that may improve the delivery of trauma care to older adults in the prehospital and emergency department phases of care.

To our knowledge, there are no Canadian guidelines for the management of trauma in older adults. The Eastern Association for the Surgery of Trauma published geriatric trauma practice management guidelines in 2012.35 These guidelines recommend lowering the threshold for trauma team activation for patients aged 65 years or older, and stress the importance of a base deficit value to predict mortality and the need for intensive care. The geriatric trauma management guidelines of the American College of Surgeons Trauma Quality Improvement Program similarly recommend a lower threshold for trauma team activation for older adults and suggest consideration of obtaining specific tests, including electrocardiography and determination of the lactate or base deficit value. ${ }^{39}$ The guidelines for field triage of injured patients (recommen- dations of the National Expert Panel on Field Triage) state that older adults (age $>55 \mathrm{yr}$ ) have a higher risk of injury or death; systolic blood pressure less than $110 \mathrm{mmHg}$ may represent shock in those older than 65; and low-impact mechanisms (e.g., ground-level falls) may result in severe injury. ${ }^{33}$ Ichwan and colleagues ${ }^{40}$ reported that modification of Ohio's 2009 emergency medical services adult triage criteria for patients aged 70 years or older resulted in improved sensitivity in identifying surrogate markers of the need for trauma centre care. None of the existing guidelines provide specific recommendations for modifying trauma care of older adults in the emergency department phase of care.

There is a need for the development of new, evidencebased guidelines for the management of older patients with trauma. These guidelines should provide concrete recommendations when possible. Any guideline development should include patient stakeholders and the involvement of geriatricians. The findings of this Delphi study provide an important framework upon which guideline development can begin. In addition, future research should examine whether the suggested trauma care modifiers in this study truly improve the care of older patients with trauma. 


\section{Limitations}

Northern and eastern Canada were underrepresented on the expert panel. We attempted to recruit 30 panellists, but 6 either declined or did not respond. The single panellists from Manitoba and Alberta were trauma surgeons, and the single panellist from Nova Scotia was an emergency physician. Second, we did not conduct any in-person meetings with expert panellists. It is possible that such a meeting may have led to different suggestions for new modifiers and potentially different scoring of items based on in-person discussion. However, our modified Delphi approach kept the identity of each panellist blinded in order to minimize bias with respect to scoring items. Third, we did not involve members of the public. We feel strongly that future steps taken toward guideline development should involve older adult patient stakeholders. Finally, the findings of this study may not be generalizable to other settings, where the trauma population may differ substantially.

\section{Conclusion}

Using a modified Delphi process, an expert panel agreed on 17 trauma care modifiers for adults aged 65 years or older in the prehospital and emergency department phases of care. These modifiers may improve the delivery of trauma care for older adults and should be considered when developing local and national trauma guidelines.

Affiliations: From the Department of Emergency Medicine, University of Ottawa, Ottawa, Ont. (Yadav); Université Laval, Québec, Que. (Boucher, Le Sage, Mercier, Voyer, Clement, Emond); and McGill University, Montréal, Que. (Malo).

\section{Competing interests: None declared.}

Contributors: K. Yadav and M. Émond designed the study, with assistance from all other authors. K. Yadav analyzed the data and wrote the manuscript, which all authors critically revised. All authors gave final approval of the article to be published.

Content licence: This is an Open Access article distributed in accordance with the terms of the Creative Commons Attribution (CC BYNC-ND 4.0) licence, which permits use, distribution and reproduction in any medium, provided that the original publication is properly cited, the use is noncommercial (i.e., research or educational use), and no modifications or adaptations are made. See: https://creativecommons. org/licenses/by-nc-nd/4.0/.

\section{References}

1. Bushnik T, Tjepkema M, Martel L. Health-adjusted life expectancy in Canada. Health Rep 2018;29:14-22.

2. Baker SP, O'Neill B, Haddon W Jr, et al. The injury severity score: a method for describing patients with multiple injuries and evaluating emergency care. 7 Trauma 1974;14:187-96.

3. Joseph A. Trauma in the elderly: Burden or opportunity? Injury 2015;46:1701-2.

4. Kehoe A, Smith JE, Edwards A, et al. The changing face of major trauma in the UK. Emerg Med F 2015;32:911-5.

5. Beck B, Cameron P, Lowthian J, et al. Major trauma in older persons. BFS Open 2018;2:310-8.

6. ATLS - Advanced trauma life support. 10th ed. Chicago: American College of Surgeons Committee on Trauma; 2018.
7. Moons P, Arnauts H, Delooz HH. Nursing issues in care for the elderly in the emergency department: an overview of the literature. Accid Emerg Nurs 2003;11:112-20.

8. McCabe JJ, Kennelly SP. Acute care of older patients in the emergency department: strategies to improve patient outcomes. Open Access Emerg Med 2015;7:45-54.

9. Kocuvan S, Brilej D, Stropnik D, et al. Evaluation of major trauma in elderly patients - a single trauma center analysis. Wien Klin Wochenschr 2016;128(Suppl 7):535-42.

10. Taylor MD, Tracy JK, Meyer W, et al. Trauma in the elderly: intensive care unit resource use and outcome. 7 Trauma 2002;53:407-14.

11. Herron J, Hutchinson R, Lecky F, et al. The impact of age on major orthopaedic trauma: an analysis of the United Kingdom Trauma Audit Research Network database. Bone foint 7 2017;99-B:1677-80.

12. Caterino JM, Valasek T, Werman HA. Identification of an age cutoff for increased mortality in patients with elderly trauma. Am 7 Emerg Med 2010;28:151-8.

13. Lukin W, Greenslade JH, Chu K, et al. Triaging older major trauma patients in the emergency department: an observational study. Emerg Med F 2015;32:281-6.

14. Chang DC, Bass RR, Cornwell EE, et al. Undertriage of elderly trauma patients to state-designated trauma centers. Arch Surg 2008; 143:776-81, discussion 782.

15. Grant PT, Henry JM, McNaughton GW. The management of elderly blunt trauma victims in Scotland: Evidence of ageism? Injury 2000;31:519-28.

16. Lane P, Sorondo B, Kelly JJ. Geriatric trauma patients - Are they receiving trauma center care? Acad Emerg Med 2003;10:244-50.

17. Lehmann R, Beekley A, Casey L, et al. The impact of advanced age on trauma triage decisions and outcomes: a statewide analysis. Am 7 Surg 2009;197:571-4, discussion 574-5.

18. St John AE, Rowhani-Rahbar A, Arbabi S, et al. Role of trauma team activation in poor outcomes of elderly patients. 7 Surg Res 2016;203: 95-102.

19. Rogers A, Rogers F, Bradburn E, et al. Old and undertriaged: a lethal combination. Am Surg 2012;78:711-5.

20. Uribe-Leitz T, Jarman MP, Sturgeon DJ, et al. National study of triage and access to trauma centers for older adults. Ann Emerg Med 2020;75:125-35.

21. Kehoe A, Smith JE, Bouamra O, et al. Older patients with traumatic brain injury present with a higher GCS score than younger patients for a given severity of injury. Emerg Med f 2016;33:381-5.

22. Heffernan DS, Thakkar RK, Monaghan SF, et al. Normal presenting vital signs are unreliable in geriatric blunt trauma victims. 7 Trauma 2010;69:813-20.

23. Caterino JM, Raubenolt A, Cudnik MT. Modification of Glasgow Coma Scale criteria for injured elders. Acad Emerg Med 2011;18: 1014-21.

24. Werman HA, Erskine T, Caterino J, et al. Development of statewide geriatric patients trauma triage criteria. Prehosp Disaster Med 2011;26: $170-9$.

25. Callaway DW, Shapiro NI, Donnino MW, et al. Serum lactate and base deficit as predictors of mortality in normotensive elderly blunt trauma patients. 7 Trauma 2009;66:1040-4.

26. Salottolo KM, Mains CW, Offner PJ, et al. A retrospective analysis of geriatric trauma patients: venous lactate is a better predictor of mortality than traditional vital signs. Scand 7 Trauma Resusc Emerg Med 2013;21:7.

27. Neville AL, Nemtsev D, Manasrah R, et al. Mortality risk stratification in elderly trauma patients based on initial arterial lactate and base deficit levels. Am Surg 2011;77:1337-41.

28. Mock K, Keeley J, Moazzez A, et al. Predictors of mortality in trauma patients aged 80 years or older. Am Surg 2016;82:926-9.

29. Martin JT, Alkhoury F, O'Connor JA, et al. 'Normal' vital signs belie occult hypoperfusion in geriatric trauma patients. Am Surg 2010;76:65-9. 
30. Fitch K, Bernstein SJ, Aguilar MD, et al. The Rand/UCLA appropriateness method user's manual. Santa Monica (CA): RAND Corporation; 2001.

31. Hasson F, Keeney S, McKenna H. Research guidelines for the Delphi survey technique. 7 Adv Nurs 2000;32:1008-15.

32. Diamond IR, Grant RC, Feldman BM, et al. Defining consensus: a systematic review recommends methodologic criteria for reporting of Delphi studies. 7 Clin Epidemiol 2014;67:401-9.

33. Sasser SM, Hunt RC, Faul M, et al. Guidelines for field triage of injured patients: recommendations of the National Expert Panel on Field Triage, 2011. MMWR Recomm Rep 2012;61(RR-1):1-20.

34. Brown JB, Gestring ML, Forsythe RM, et al. Systolic blood pressure criteria in the National Trauma Triage Protocol for geriatric trauma: 110 is the new 90. 7 Trauma Acute Care Surg 2015;78:352-9.

35. Calland JF, Ingraham AM, Martin N, et al. Evaluation and management of geriatric trauma: an Eastern Association for the Surgery of
Trauma practice management guideline. 7 Trauma Acute Care Surg 2012;73(Suppl 4):S345-50.

36. Bouzat P, Raux M, David JS, et al. Chest trauma: first 48 hours management. Anaesth Crit Care Pain Med 2017;36:135-45.

37. Shetty VS, Reis MN, Aulino JM, et al. ACR Appropriateness Criteria Head Trauma. 7 Am Coll Radiol 2016;13:668-79.

38. Harrop JS, Rymarczuk GN, Vaccaro AR, et al. Controversies in spinal trauma and evolution of care. Neurosurgery 2017;80(3S):S23-32.

39. American College of Surgeons Trauma Quality Improvement Project Geriatric Trauma Management Guidelines. 2013. Available: https:// www.facs.org/-/media/files/quality-programs/trauma/tqip/geriatric_ guidelines.ashx (accessed 2019 Apr. 21).

40. Ichwan B, Darbha S, Shah MN, et al. Geriatric-specific triage criteria are more sensitive than standard adult criteria in identifying need for trauma center care in injured older adults. Ann Emerg Med 2015;65: 92-100.e3 